\title{
A Statement on Behalf of the Publisher and the Editorial Leadership of Vetus Testamentum
}

Brill and the Editors of Vetus Testamentum recently learned that our former Editor-in-Chief Professor Jan Joosten has been sentenced by a court in France over possession of child pornography. We are deeply shocked by these facts and express our sincere sympathy with all victims and their families. This admitted behavior violates our moral standards. Although Professor Joosten retired as Editor-in-Chief of Vetus Testamentum in 2019, he remained on the Editorial Board. We strongly renounce his abhorrent behavior and have removed Professor Joosten from the Editorial Board with immediate effect. He has also been removed as General Secretary of IOsOT, and replaced by Professor Annette Schellenberg, current Editor-in-Chief of Vetus Testamentum.

Jasmin Lange, CPO BRILL

Louise Schouten, Publishing Director BRILL

Suzanne Mekking, Senior Acquisitions Editor BRILL

Liesbeth Hugenholtz, Editor BRILL

Annette Schellenberg, Editor-in-Chief Vetus Testamentum

Christl Maier, Editor-in-Chief Vetus Testamentum Supplements

Jeremy Hutton, Associate Editor Vetus Testamentum

Joachim Schaper, Book Review Editor Vetus Testamentum 